\title{
Factors affecting grade point average among nursing students at college of applied medical science
}

\section{Uygulamalı tıp bilimleri fakültesinde hemşirelik öğrencileri arasında not ortalamasinı etkileyen faktörler}

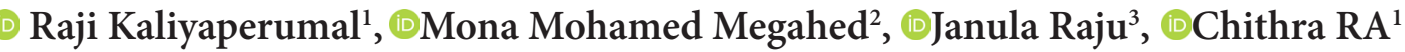 \\ ${ }^{1}$ Department of Medical Surgical Nursing, King Khalid University, Saudi Arabia. \\ ${ }^{2}$ Ministry Of Health, Technical Health Institute, Nursing Department, El Mansoura City, Egypt \\ ${ }^{3}$ Department of Maternity Nursing, King Khalid University, Saudi Arabia
}

Cite this article as/Bu makaleye atıf için: Kaliyaperumal $\mathrm{R}$, Megahed MM, Raju J, Chithra RA. Factors affecting grade point average among nursing students at college of applied medical science. J Health Sci Med 2020; 3(4): 436-441.

\begin{abstract}
Introduction: Academic performance of the students is very important. Hence, this study aims to assess the Factors affecting Grade Point Average (GPA) among nursing students at the college of applied medical science.

Material and Method: A descriptive study design was adopted in this study. A total of 134 students undergoing a 4 years of Baccalaureate nursing program at the College of Applied Medical Sciences, King Khalid University (KKU), Saudi Arabia was selected using convenience sampling. This study was carried out during the academic year of 2018-2019. The data were collected using a questionnaire such as the fivepoint Likert scale. The responses obtained were subjected to statistical analysis using SPSS.

Results: The results indicated that the factors which influence the GPA were teacher factor highest mean score 61.32, followed by student factors represented 54.77, home, the college factor is not showing many influencing factors.

Conclusion: Based on the study findings, the results revealed that the teacher-related factor had the highest grand mean value of 61.32 followed by item student-related factor had the grand mean value of 54.77 , home factor grand mean value of 47.27 , and college factor grand mean value of 20.17. Result revealed that teacher plays a key role in the academic performance of the students. So the present study concludes that the teacher should get feedback from the students at the end of each class to make sure whether the students understood the lecture and clarify the doubt of the students at the end of each lecture.
\end{abstract}

Keywords: Factors, grade point average (GPA), nursing students

ÖZ

Giriş: Öğrencilerin akademik performansı çok önemlidir. Bu nedenle bu çalışma, uygulamalı tıp bilimleri kolejindeki hemşirelik öğrencileri arasında not ortalamasını (NO) etkileyen faktörleri değerlendirmeyi amaçlamaktadır.

Gereç ve Yöntem: Bu çalışmada betimsel çalışma tasarımı benimsenmiştir. Suudi Arabistan Kral Halid Üniversitesi (KKU) Uygulamalı Tıp Bilimleri Koleji’nde 4 Ylllık Bakalorya hemşireliği programına giren toplam 134 öğrencinin uygunluk durumuna göre örneklem seçildi. Bu çalışma 2018-2019 eğitim öğretim yılında yapılmıştır. Veriler, beş noktalı Likert ölçeği gibi bir anket kullanılarak toplanmıștır. Elde edilen yanıtlar SPSS kullanılarak istatistiksel analize tabi tutulmuştur.

Bulgular: Sonuçlar, not ortalamasını etkileyen faktörlerden öğretmen faktörünün en yüksek ortalama puan 61,32 olduğunu, ardından öğrenci faktörlerinin 54,77’yi temsil ettiğini, üniversite faktörünün önemli ölçüde etkileyici özelliği olmadığını gösterdi.

Sonuç: Araştırma bulgularına göre, sonuçlar öğretmenle ilişkili faktörün en yüksek genel ortalama değeri olan 61,32 olduğunu, öğrenciyle ilişkili faktörün genel ortalama değeri 54,77 olduğunu, ev faktörünün büyük ortalama değerinin 47,27 olduğunu ve üniversite faktörünün büyük ortalama değerinin 20,17 olduğunu gösterdi. Sonuçta öğretmenin, öğrencilerin akademik performansında önemli bir rol oynadığını ortaya konulmuştur. Bu nedenle mevcut çalışma öğretmenin, öğrencilerin dersi anlayıp anlamadıklarından emin olmak ve her dersin sonunda öğrencilerin şüphelerini açıklığa kavuşturmak için öğrencilerden geribildirim alması gerektiği sonucuna varmaktadır.

Anahtar Kelimeler: Faktörler, not ortalaması, hemşirelik öğrencileri 


\section{INTRODUCTION}

Students are the future leader of the nation. Academic achievement of the students play an important role in producing best quality graduate nurses. Baccalaureate nursing student nurses are the future healthcare professionals to save the life of the patient. Student performance is one of the important factors to know the quality of education and also the guiding post to know about the lack of education. If the performance is the measure and it is possible to rectify the factor which reduces the performance and helps not only students and also the teacher to identify the problem in education. Few investigators also described that a student who is successful in their required profession has good study habits. In addition to this, she explained that students should apply these habits to in their daily studies. She also suggested that the students should not try to study all the subjects in a single period of time (1).

A study found that the student's previous educational outcome had the most important sign of students'upcoming achievement. This indicates that the highest the previous appearance, the better academic performance of the student in future endeavors (2).

Academic success has a great influence on a student's self- esteem, motivation, and perseverance in higher education. Poor academic performance or highest failure rates may lead to undesirable levels of school dropping, less graduation, and high cost of education. This may also decrease the chance of higher education. Parents'participation has been measured in different ways. The study found that increase occurrence of performance was linked with poor performance or misbehavior in the classroom (3).

An efficient and good Teachers are continuously on the improvement of teaching or instructional material, which may result in efficient learning of students. A sensible and clever choice of a selection of teaching material or audiovisual aids leads to good level of understanding. Some of the factors affecting the student's academic performance such as personal condition, school-related aspect, study habits, home-related aspect, and teacher-related aspect. These factors have highly effect on students'performance, the degree of impact of these factors differs according to personality and culture. Regarding, school-related factor, it was found that unqualified and less efficient teachers, lack of facilities, and inadequate instructional materials were mainly affecting the academic achievement of students. Non-school factors include poverty, low educational achievement, lack of education of parents, poor health, and dietary pattern were the major factors that affect the academic performance (4).
Factors affecting students'academic performance arise for several reasons. Thinking skills primarily affect students learning factors. If they do not learn what they need to learn. If the teacher does not know how to catch the attention of the students, the more students cannot make attention to the subject. The students get lazy if they perceive the topic is not relevant to their subject (5).

The higher education performances depend on the academic achievement of graduate students (6). The outcome of student previous education has the most significant sign of student's upcoming performances, It indicates that the higher previous appearance the better student academic performance in future activities (2). Social and economic background of parents may be linked with the academic performance of school students, they noticed that parents or guardians who have well established social, educational and economic background definitely make stronger the level of a successful career in the future (7).

The students who are successful in their preferred career have interest in reading habits. The researcher stated that students should follow these reading habits to all of their subjects. She also suggested that the students should try to study all their subjects in a different period of time. The personal characteristics of learners and the environment play an important role in their academic success (8). The family members, school personnel, and community provide help and support to improve the quality of the academic performance of the students. This social assistance plays a vital role in the accomplishment of the performance of students at school (9).

Students whose parents are educated secured higher score on standardized tests than those whose parents were not educated (10). Educated parents can well communicate with their children regarding completing schoolwork, activities, and information being taught at school (11). The home environment also influences the academic performance of students. Educated parents can provide such an environment suitable for the academic success of their children. The academic performance of students profoundly depends upon parental involvement in their academic activities to attain the highest level of quality in academic success (12).

A lot of research has been done on factors affecting the academic performance of the college students but there is less information about the academic performance of the students. There are many factors which affect the learning process of learner. The literature suggests that there are many variables that affect learning such as environment, nutrition, emotions, gender, sleep, culture, learning style, and previous learning experience (13). The teacher should know how to make the students understand 
more about the subject which they are teaching and also identify the factors which affect their learning and guide them to overcome the problem. This makes the students perform well in their examinations. Hence, students, academic performance has always been a topic of interest for educator. Educators and researchers have identified demographic, socio-economic, family and school factors as variable contributing to students academic performance. Keeping this in mind, the researcher selected this topic to identify the factors which affect their learning and reduce the GPA.So this study aims to identify the factor that leads to reduce the GPA among female nursing students and to associate the demographic data and GPA.

\section{MATERIAL AND METHOD}

All procedures were performed adhered to the ethical rules and the Helsinki Declaration of Principles. The study was carried out with the permission of King Khalid University (Permission date: 11.2.2019, No: HA06-B-001).

A quantitative, descriptive - survey method was adopted for this study. The study was conducted in the College of applied medical science, Saudi Arabia. The college is providing 4 years Baccalaureate degree nursing program. Students from level 3 to level 8 were $\left(2^{\text {nd }}\right.$ year $-4^{\text {th }}$ year $)$ recruited to participate in the study based on the inclusion criteria such as willing to participate in the study and the exclusion criteria was level $1 \& 2\left(1^{\text {st }}\right.$ year $)$ students because in the first year the subjects were related to basic science not the nursing subject. A total of 134 students consent to participate in the study from level 3 to level 8 $\left(2^{\text {nd }}\right.$ year $-4^{\text {th }}$ year) between the age group of 18-23 years. The sample were selected based on convenient sampling technique. The tools used for the study was totally 10 questions regarding personal information, Such as Student age, marital status, number of family members, family income, number of the family at home, Family chronic disease, Selection of nursing course, Respondent chronic illness, A number of hours traveling from home to college, GPA and also rating scale for assessing the factors influencing the academic performance of the students. The questionnaire used for assessing the factors affecting GPA is composed of 49 questions classified as student related factor (14 questions), college related factor (6 questions), Home related factor (14 question) and Teacher related factor (15 questions). The scale is composed of five-point Likert as 1 (Never), 2 (rarely), 3 (sometime), 4 (often), 5 (always). The questionnaire used for data collection was translated to the Arabic version. The tool was validated by the expert in the field of nursing, Using Cronbach Alpha, the instrument was found to be highly reliable as indicated by the value of 0.84 .

\section{Method of Data Collection}

The researcher got permission from the college Administrative authority. Thereafter, it was subjected to review by the Research Ethics Committee of the university. Based on approval the researcher preceded the data collection. The researcher informed the purpose of the study and the confidentiality of the personal data. The data will be used only for study purpose and the benefit of the study explained to the students and informed consent collected from the students. The researcher explained that their participation was entirely voluntary, that there was no monetary compensation for their participation, and that any information resulting from the study was strict confidentiality. The researcher provided detail about the questionnaire and how to rate the questionnaire themselves and their personal information. Arabic version of a questionnaire distributed to the students individually according the willingness, consent for participating in the study also collected before starting to filling the data and instructed them to rate the scale according to their experience about these factors and also said this is about their individual opinion should not discuss with their friends. Each students taken 30-45 minutes to complete the questions and the data collection period was 3 weeks. The obtained data were reviewed, prepared for computer processing, coded, analysed, and tabulated. Data entry and data analysis were done using SPSS version 16. Data were presented as Frequency distribution, Mean, Standard Deviation, correlation.

\section{RESULTS}

Figure shows the distribution of students participation in the study according to the academic levels, level 3, level $48 \%$ and $25 \%$ level 5, level $616 \%$ \& $24 \%$, level 7 , level $814 \%$ \& $13 \%$. The results demonstrate that 2 nd \& 3rd students participation is high than final year students (Figure 1).

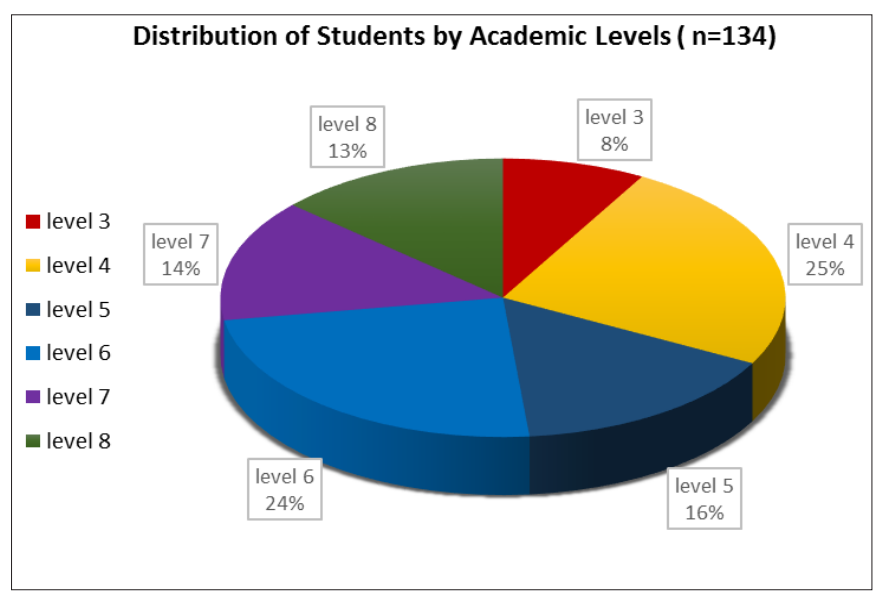

Figure 1. Distribution of students by academic levels 
Total number of students was 134, majority of them (84.3\%) were single, $87.3 \%$ were free from chronic diseases, $91.8 \%$ were selecting nursing specialty by themselves and $63.4 \%$ their family income was $>10000$ SR. This shows that majority of the students selected nursing course on their own so they shows the interest in studying the nursing subject and also sickness of the family members and the financial aspect of the family members also is good and it is not the factor to influence the study (Figure 2).

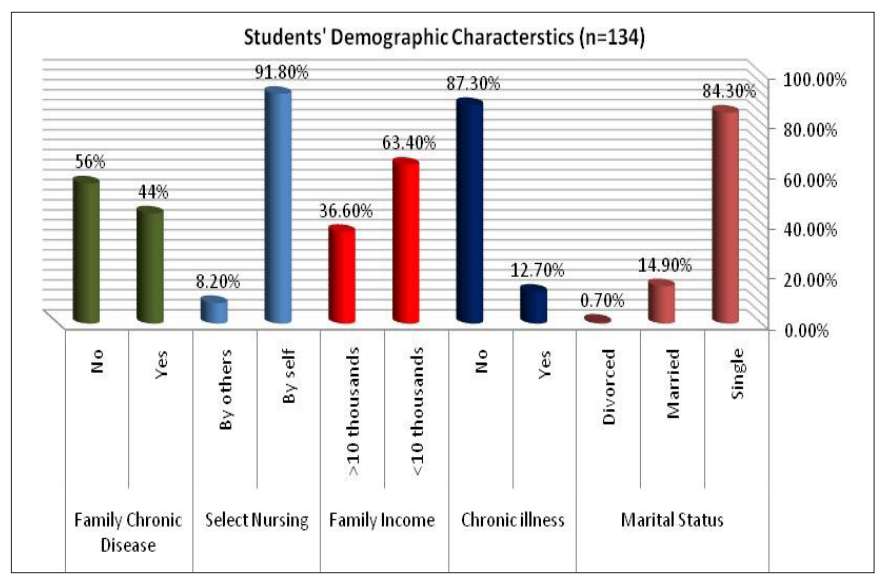

Figure 2. Distribution of students by academic levels

As regard students'demographic characteristics mean score, students'mean age was 21.52 years, number of family members 7. 94, GPA Mean score was 3.13 and Mean hours the students spent to reach college was 1.38. This shows majority of the participants between the age group of 21 years (Table 1 ).

\begin{tabular}{|lc|}
\hline \multicolumn{2}{|l|}{ Table 1. Students Demographic Characteristics Mean Score } \\
\hline Items & Mean $(\overline{\mathbf{X}} \pm$ SD $)$ \\
\hline Age & $21.52+1.193$ \\
Family number & $7.94+3.117$ \\
GPA & $3.13+0.758$ \\
Hours to college & $1.38+0.805$ \\
\hline
\end{tabular}

There are 4 factors such as Student, College, Home and Teacher identified to know which factor affecting the students GPA. The result revealed that the teacherrelated factor had the highest Grand Mean Value of 61.32 followed by item student related factor had the Grand Mean Value of 54.77,Home factor Grand Mean Value of 47.27 and college factor Grand Mean Value of 20.17. This shows that teacher factor influence on GPA of the students. (Table 2).
Table 2. Factors Affecting Students GPA Mean Score

\begin{tabular}{|ll|}
\hline Items & Mean $(\overline{\mathbf{X}} \pm$ SD $)$ \\
\hline Student factors & $54.7761 \pm 7.01517$ \\
College factors & $20.1716 \pm 3.07189$ \\
Home factors & $47.2761 \pm 9.55978$ \\
Teacher factors & $61.3284 \pm 11.87768$ \\
\hline
\end{tabular}

It shows the correlation between factors and students'GPA, there was positive correlation between college factors and students'factors $(\mathrm{r}=.353, \mathrm{p}=0.01)$, students'factors and teacher factors $(\mathrm{r}=.327, \mathrm{p}=0.01)$, teacher factors and college factors $(\mathrm{r}=.399, \mathrm{p}=0.01)$, while no correlation founded between home factors and students'GPA. This implies Student, College and Teacher factors play a important role in the improving students GPA (Table 3).

\begin{tabular}{|lccccc|}
\hline Table 3. Bivariate Correlations between Factors and Students GPA \\
\hline Item & $\begin{array}{c}\text { Student } \\
\text { factors }\end{array}$ & $\begin{array}{c}\text { Home } \\
\text { factors }\end{array}$ & $\begin{array}{c}\text { College } \\
\text { factors }\end{array}$ & $\begin{array}{c}\text { Teacher } \\
\text { factors }\end{array}$ & GPA \\
\hline Student factors & 1 & .088 & $.353^{* *}$ & $.327^{* *}$ & .021 \\
Home factors & .088 & 1 & $-.125-$ & .096 & .030 \\
College factors & $.353^{* *}$ & $-.125-$ & 1 & $.399^{* *}$ & .052 \\
Teacher factors & $.327^{* *}$ & .096 & $.399^{* *}$ & 1 & .024 \\
GPA & .021 & .030 & .052 & .024 & 1 \\
\hline${ }^{* *}$ Correlation is significant at the 0.01 level (2-tailed). \\
${ }^{*}$ Correlation is significant at the 0.05 level (2-tailed). \\
\hline \multicolumn{7}{|l}{} \\
\hline
\end{tabular}

It shows the correlation between demographic characteristics and GPA of the students. The result shows negative correlation between students'age $(r=-$ .258, $\mathrm{p}=0.01$ ) and GPA, so the age of the students is not matter for the GPA of the students, age and year of study shows positive correlation $(\mathrm{r}=.628, \mathrm{p}=0.01)$, so the year of the study increases the understanding and interest of the study will be good and thus the students GPA also increases and number of family members have positive correlation to hours to college $(r=.190$, $\mathrm{p}=0.05)$ (Table 4).

\begin{tabular}{|c|c|c|c|c|c|}
\hline Item & GPA & Age & Level & $\begin{array}{c}\text { Family } \\
\text { Number }\end{array}$ & $\begin{array}{c}\text { Hours to } \\
\text { College }\end{array}$ \\
\hline GPA & 1 & $-.258^{\star *}$ & .021 & $-.046-$ & .018 \\
\hline Age & $-.258^{\star \star}$ & 1 & $.628^{* *}$ & .034 & $-.003-$ \\
\hline Level & .021 & $.628^{* *}$ & 1 & $-.048-$ & $-.131-$ \\
\hline Family members & $-.046-$ & .034 & -.048 & 1 & $.190^{*}$ \\
\hline Hours to college & .018 & $-.003-$ & $-.131-$ & $.190^{*}$ & 1 \\
\hline
\end{tabular}




\section{DISCUSSION}

This study was conducted to explore the important factor that affects the students Grade Point Average. The aim of nursing education is to acquire knowledge, attitude, and skills to provide quality nursing care to needy people. The students should perceive the importance of education and improve professional standards. The current study was conducted to explore the factors which affect the GPA. The current study revealed that most of the nursing students in the age group of 21 years. Regarding the Grade Point Average most of the students were in the category of 3.13.The results show that the average number of family members have seven to nine members in the family.

Findings indicate that all the factors to students, school, home, and teacher have an extensive effect on the academic performance of the student's respondents. Results further revealed that among the four given factors, teacher-related factors have the greatest impact on the academic performance as indicated by the mean value of 61.32 . This further indicates that the respondents felt that teaching strategies, student-teacher relationships, and communication barriers hinder their academic performance. This results supported by the study conducted by Alos et al. (14) (2015) which concluded some of the factors have a great impact on the performance of the students, teacher-related factor top the list. This shows that teacher plays an important role in the performance of the students.

Ganyaupfu (15) (2013) also indicates that teacher competence in teaching is a combination of paradigm in the sense that it measures a variety of interrelated aspects in teaching which includes mastery in the subject, preparing the subject in detail, presentation of the content, and effective communication with the students. Lack of knowledge in the subject matter by the teacher leads frustration among students by fulfilling the expectation of the students. Richardson (16) (2006) drawn from the research results teachers have impact on the student's academic performance and from the results, they recommended commitment in preparing the subject and pacing the information, maintain good communication is very important.

The second factor which affects the performance of the students was student-related factors. Manizheh Alami (17) (2016) who said that there could be any reason for students'boredom in the class untouchable topics to read or write and mismatch between students'current information and the presented material in the classroom, I study only there is exam. Moreover et al. (18) (2015) said that high-performance students study in a calm and lonely place most of the time, the study at a consistent time throughout the semester, note an important point in the lecture and clarify the doubt. Meenu (19) (2016) indicated that family structure has a great influence on the student's academic achievement. It is generally reported that the un-conducive environment at home reduces the possibility of learning capabilities.

The third factor which affects student performance was a home-related factor. Bonci (20) (2008) noted in her study that home plays a major role in the achievement of the students. Other researchers also noted that the lack of support from the home leads to a decline in the performance of the students. This normally happens in the urban area most of the parents used to be busy in their office work and it is difficult for them to spend time with their children for guiding them to prepare for the studies. The parents have no attention towards students and therefore spend most of their time in the social media. Using social media distraction from the studies and the students are not ready to prepare the lesson on a daily basis this makes them prepare the lesson only during the exam time.

The last factor which affects the performance of the students is college-related factors. These factors include the availability and perceived quality of learning facilities such as the library, computer, laboratory, clinical environment. Schools without basic facilities also affect the student's performance. The classroom physical environment is very important for students to concentrate in the class and also the facility in the laboratory. Nursing students spend most of their hours in the laboratory and in hospitals. If they practice in the hospital whatever they learned in the classroom makes them understand well and also it give confidence about the subject matter. Owoeye et al. (21) (2011) said that the main purpose of a school library is to make all books, periodicals and other reproduced materials available to the students to improve their study habits. They further indicated that school libraries may not be effective if the books therein are not adequate and up to date. The library environment should have a comfortable environment, chairs and rich in literature with adequate books, journal, periodicals, magazine, computer copy machines and other learning aids that help the students to perform well and that they may need sufficient space for their study so that they do not need to squeeze themselves together. Studies show that students will not perform well if the environment is too hot or too cold, the environment should be conducive for concentrating the class lecture. The inadequate facility in the college environment also leads to health problems.

\section{CONCLUSION}

Based on the study findings, the results revealed that teacher-related factor was highly influencing and the other factor such as student, home and college followed that. Among the teacher factor there are two statements 
shown highest score such as Do your teacher provide an explanation in the class and Do your teacher clarify the doubt if you have any doubt in the subject matter has highest mean score, it is considered as highly influencing factor. so at the end of each class the teacher should get feedback from the students and modify their teaching strategy according to the need.

\section{ETHICAL DECLARATIONS}

Ethics Committee Approval: The study was carried out with the permission of King Khalid University (Permission date: 11.2.2019, No: HA-06-B-001).

Informed Consent: Consent form was obtained from the students.

Conflict of Interest Statement: The authors have no conflict of interest to declare.

Financial Disclosure: The authors declared that this study has received no financial support.

Author Contribution: All of the authors declare that they have all participated in the design, execution, analysis of the data.

Acknowledgement: We would like to thank the university for given ethical approval for conducting study and students for participation in the research.

\section{REFERENCES}

1. Marquez VC, Romero C, Ventura S. Predicting School Failure Using Data Mining. In Proceedings of the $4^{\text {th }}$ International Conference on Educational Data Mining. 2011; 6: 271-6.

2. Bratti M, Staffolani S. Student time allocation and educational production functions, Conference paper at the XIV annual EALE conference. 2002.

3. Schlee BM, Mullis AK, Shriner M. Parents Social and Resource Capital: Predictors of academic achievement during early childhood. Children and youth services review. J Educ Psychol 2008; 96: 778-84.

4. Alos SB, Caranto LC, David JJT. Factors Affecting the Academic Performance of the Student Nurses of BSU. Int J Nurs Sci 2015; 5: 60-5

5. Stomberg M, Nilsson K. Nursing students'self-graded motivation to complete their programme of study. Open Nurs J 2010; 4: 42-7.

6. Soares AP, Guisande MA, Almeida LS, Paramo M.F. Academic Achievement in first-year Portuguese college students: The role of academic preparation and learning strategies. Int J Psychol 2009; 44: 204-12.

7. Zhonglu L, Zeqi Q. How does family background affect children's Educational achievement? Evidence from Contemporary China. Chin J Sociol 2018; 5: 13

8. Hayden K, Ouyang Y, Scinski L, Olszewski B, Bielefeldt T. Increasing student interest and attitudes in STEM: Professional development and activities to engage and inspire learners. CITE 2011; 11: 47-69.

9. Goddard RD. Relational networks, social trust, and norms: A social capital perspective on students'chances of academic success. Educ Eval Policy Anal 2003; 25: 59-74.

10. Krashen S. The hard work hypothesis: Is doing your homework enough to overcome the effects of poverty? Multicult Educ 2005 1: 16-9.
11. Fantuzzo J, Tighe E. A family involvement questionnaire. J Educ Psychol 2000; 92: 367-376.

12. Barnard WM. Parent involvement in elementary school and educational attainment. Child Youth Serv Rev 2004; 26: 39- 62.

13. Jensen B, Seltzer A. Neighbourhood and family effects in educational progress. Aust Econ Rev 2000; 33: 17-31.

14. Alos SB, Caranto LC, David JJT. Factors affecting the academic performance of the student nurses of BSU. Int J Nurs Sci 2015; 5: 60-5.

15. Elvis MG. Factors influencing academic achievement in quantitative courses among business students of private higher education institutions.J Educ Pract 2013; 4: 57-60.

16. Richardson JTE. Investigating the relationship between variations in students perceptions of their academic environment and variations in study behaviour in distance education. Br J Educ Psychol 2006; 76: 867-893

17. Manizheh A. Causes of poor academic performance among omani students. Int J Soc Sci Res 2016; 4: 8-11.

18. Miguel AC, Ksenia P. Influence of study habits on academic performance of International college students in Shanhai. CCSE 2015; 5: 42-55

19. Meenu D. Factors affecting the academic achievement: A study of elementary school students of NCR Delhi, India. J Educ Pract 2016; 7: 70-4

20.Bonci A. A research review: The importance of families and the home environment, National Literacy Trust. 2008; Retrieved from https://files.eric.ed.gov/fulltext/ED521654.pdf

21. Joseph S, Owoeye Y. School facilities and academic achievement of secondary school agricultural science in Ekiti state, Nigeria. Asya Soc Sci 2011; 7: 64-74. 